\title{
Ultrastructure of the Penetration and Infection of Pansy Roots by Thielaviopsis basicola
}

\author{
Charles W. Mims, Warren E. Copes, and Elizabeth A. Richardson
}

First author: Department of Plant Pathology, University of Georgia, Athens 30602; second author: Department of Plant Pathology, Washington State University, Puyallup 98371; third author: Department of Botany, University of Georgia, Athens 30602. Accepted for publication 1 May 2000.

\begin{abstract}
Mims, C. W., Copes, W. E., and Richardson, E. A. 2000. Ultrastructure of the penetration and infection of pansy roots by Thielaviopsis basicola. Phytopathology 90:843-850.

Transmission electron microscopy was used to study the penetration and infection of pansy roots by Thielaviopsis basicola. Events observed in 7- to 10-day-old roots produced on moist filter paper differed slightly from those in roots from 4-week-old plants washed free of potting media prior to inoculation. By $3 \mathrm{~h}$ postinoculation (PI), epidermal cells of roots produced on filter paper exhibited aggregated cytoplasm and papilla formation in response to germ tube tips. The presence of callose in papillae was demonstrated using immunogold labeling. Papilla formation was not effective in preventing host cell penetration. A slender infection hypha emerged from a germ tube tip and grew through a papilla. Its tip then expanded to form a globose infection vesicle. By $6 \mathrm{~h}$ PI, infection
\end{abstract}

ABSTRACT

Thielaviopsis basicola (Berk. \& Broome) Ferraris (synanamorph Chalara elegans Nag Raj \& Kendrick) is a soilborne fungus that attacks the roots of a wide variety of economically important plants (18). In a recent study, Hood and Shew (8) reported that the behavior of $T$. basicola during the infection of tobacco root hairs was typical of a hemibiotrophic pathogen. Such pathogens are characterized by the fact that they initially require living host cells for infection to occur but subsequently become necrotrophic and typically sporulate on dead tissues of their host (12). However, the lengths of the biotropic phases exhibited by these types of fungi appear to vary greatly. According to Parbery (19), hemibiotrophs can be divided into biotrophic hemibiotrophs and necrotrophic hemibiotrophs. The former group includes species in which colonization of host tissues is entirely biotrophic, with the death of host cells delayed until about the time the pathogen begins to sporulate. Necrotrophic hemibiotrophs, on the other hand, have a short biotrophic phase that allows them to take possession of host tissue prior to killing and invading the tissue. Examples of necrotrophic hemibiotrophs include various species of Colletotrichum (10,17,27), including C. lindemuthianum (16), the cause of bean anthracnose disease and, based on the observations of Hood and Shew (8), apparently also T. basicola. The object of the present study is elucidate precise ultrastructural details relating to the early events involved in the penetration and infection of pansy (Viola $\times$ wittrockiana Gams.) roots by $T$. basicola. As noted by Parbery (19), this type of information is badly needed for various types of hemibiotrophic pathogens.

As noted by Hood and Shew (8), there have been numerous reports of the formation of slender threadlike penetration hyphae

Corresponding author: C. W. Mims; E-mail address: cwmims@arches.uga.edu

Publication no. P-2000-0614-01R

(C) 2000 The American Phytopathological Society hyphae emerged from infection vesicles, and invaded host cells showed signs of necrosis. By $8 \mathrm{~h}$ PI, infection hyphae had grown into cortical cells in spite of papilla formation in these cells. By $24 \mathrm{~h}$ PI, distinctive intracellular hyphae were present in necrotic cortical cells. In washed roots, most epidermal cells failed to respond to invasion. Hyphae simply grew through these cells and contacted cortical cells that exhibited aggregated cytoplasm and papillae formation. Infection structures similar to those produced in epidermal cells from roots grown on filter paper then formed in cortical cells of washed roots. The fact that $T$. basicola formed infection structures only in cells that responded to invasion suggests that $T$. basicola has a more complex relationship with its host than would be expected in a nectrotrophic pathogen. We believe that $T$. basicola is best described as a necrotrophic hemibiotroph.

Additional keywords: host-pathogen relationship.

with swollen terminal vesicles in plant root cells attacked by $T$. basicola. However, prior to their study (8) of the infection of tobacco roots by $T$. basicola, the development of these distinctive infection structures had not been examined in any detail. By utilizing tobacco roots grown in agar in petri plates, Hood and Shew (8) were able to conduct a careful in situ time-course study of the penetration and infection of tobacco root hairs by $T$. basicola. Their use of nondestructive light microscopic observations allowed them to accurately document the timing and sequence of events that occurred from the moment the pathogen contacted a root hair until the time an infection vesicle developed within that same root hair. They also used transmission electron microscopy (TEM) to examine the mature infection structures of T. basicola but did not study the initial penetration and infection events using this technique. Combined with the observations of Hood and Shew (8), the results we report here should provide a detailed description of the way in which this important hemibiotrophic pathogen attacks its hosts and the ways in which host roots respond to penetration and infection.

\section{MATERIALS AND METHODS}

Maintenance of pathogen and preparation of inoculum. The isolate of $T$. basicola used in this study was obtained from roots of an infected pansy plant provided by a commercial nursery in Georgia. It was grown in the laboratory on V8 juice agar at $20^{\circ} \mathrm{C}$. The endoconidia used to inoculate pansy roots were obtained by flooding 14- to 21-day-old cultures in petri plates with sterile deionized water and rubbing the agar surface with a sterilized rubber policeman. The water then was pipetted from the plates and filtered through four layers of sterilized cheesecloth to help remove chlamydospores and hyphal fragments. The resulting suspension of endoconidia was used to inoculate pansy roots. 
Preparation of plant roots, inoculation procedures, and preparation of samples for TEM. In one experiment, University Orange pansy seeds (Park Seed Company, Grenwood, SC) first were surface-sterilized by placing them in a $10 \%$ solution of sodium hypochlorite in water for $3 \mathrm{~h}$. Seeds then were washed in multiple changes of sterile deionized water, germinated on pieces of moist sterile filter paper in petri plates, and then exposed to light. After a total of 7 to 10 days at 20 to $22^{\circ} \mathrm{C}$, roots were usually 15 to $20 \mathrm{~mm}$ long. A pipette was used to apply a suspension of endoconidia along the length of each root, and plants were incubated at 20 to $22^{\circ} \mathrm{C}$. At $3,4,6,8$, and $24 \mathrm{~h}$ postinoculation (PI), a razor blade was used to cut roots into approximately 5-mm-long sections that were prepared for TEM using a routine glutaraldehyde- $\mathrm{OsO}_{4}$ fixation procedure (23). Following dehydration and infiltration with Spurr's plastic (EM Sciences, Fort Washington, PA), root pieces were flat embedded according to the procedures of Roberts et al. (22), and light microscopy was used to select samples for thin sectioning. Observations concentrated on the zone of enlogation between the tip of each root and the zone of maturation where numerous root hairs were present. Except for one root cell shown in cross section, all other micrographs presented here are from sections cut parallel to the long axis of each root. Thin sections were cut using a diamond knife, collected on slot grids according to the procedures of Rowley and Moran (23), and poststained with uranyl acetate and lead citrate prior to examination at $80 \mathrm{kV}$ with an EM 902A electron microscope (Zeiss, Oberkochen, Germany).

In a second experiment, 4-week-old University Orange pansy plants grown in pots on Pro-Mix BX (Premier Brands Inc., Redhills, PA) in a greenhouse were utilized. These plants were brought into the laboratory where running water was used to remove all potting media from the root systems as gently as possible. Plants then were placed on moist, sterile filter paper in petri plates and roots were flooded with a suspension of endoconidia. Sampling times and procedures used to prepare roots for TEM were identical to those described above. Roots from three plants were utilized for each sampling time.

Immunocytochemistry. A polyclonal rabbit antibody $(\mathrm{CH}-11-$ 512) purchased from Cambridge Research Biochemicals (Wilmington, DE) recognizing (1-3)- $\beta$-glucans was used to detect callose in papillae formed by root cells penetrated by $T$. basicola. A secondary antibody (goat anti-rabbit immunoglobin $\mathrm{G}$ ) coupled to 10-nm gold particles purchased from Life Sciences (Arlington Heights, IL) was used in conjunction with the polyclonal antibody. Procedures and controls for labeling callose were identical to those described by Enkerli et al. (5).

\section{RESULTS}

The use of flat-embedded samples was critical to the success of this study. By examining flat-embedded roots with light microscopy (Fig. 1A through C), it was possible to locate germinated conidia and penetration sites as well as fungal structures inside root cells and then examine these same conidia and penetration sites in thin sections at the ultrastructural level. Combined light and TEM observations of specific structures and sites contributed to a much better understanding of the events involved in the penetration and infection of pansy roots by $T$. basicola. This approach not only was much more productive than the random sectioning of roots, it also made it possible to find and examine many different structures and sites from a large number of roots in a timely manner.

By $3 \mathrm{~h}$ PI, most endoconidia of $T$. basicola had germinated. Each spore produced only a single germ tube. Some germ tubes became quite long as they grew over root surfaces while others were short, apparently having ceased elongation once their tips contacted root surfaces. Hyphal tips in contact with roots typically were slightly swollen (Fig. 1A, D, and E) and, in some cases, delimited by septa (Fig. 1E). However, as shown later, septum formation was not required for penetration of pansy roots. Although the swollen germ tube tips of $T$. basicola appeared to adhere to root surfaces, there was little evidence of any extracellular material associated with such tips (Fig. 1D and E). We saw no evidence of host cell wall penetration at $3 \mathrm{~h}$ PI.

The sequence of events observed during the penetration and infection of pansy roots by $T$. basicola was slightly different for roots produced on moist filter paper in petri plates and those taken from plants grown in pots and rinsed free of potting media prior to inoculation with endoconidia. Observations for roots grown in petri dishes are presented first.

Most of the volume of an epidermal cell from a pansy root produced on filter paper was occupied by a large central vacuole that displaced the cytoplasm and nucleus to the periphery of the cell. Almost all epidermal cells in direct contact with germ tube tips exhibited a distinct accumulation of cytoplasm at the point of contact with the fungus (Fig. 1F). In many cases the host cell nucleus also was present in this region of the cell. As soon as $3 \mathrm{~h}$ PI, evidence of papilla formation was observed in response to some germ tube tips (Fig. 1G). A developing papilla appeared as an electron-transparent region containing many vesicle-like profiles of moderate electron density (Fig. 1G). The host cell nucleus often was observed near a papilla (Fig. 1H). By 4 h PI, much larger papillae were present (Fig. 1H). Each large papilla contained a central core region containing numerous vesicle-like profiles and an electron-transparent outer margin (Fig. 2A). The presence of callose in the central core but not in the margin of a papilla could be demonstrated using a polyclonal antibody that recognized (1-3)- $\beta$-glucans (Fig. 2A). This antibody also labeled (1-3)- $\beta$ glucans present in the pathogen wall (Fig. 2A).

Although formed very quickly in response to germ tube tips of T. basicola, papillae were not effective in preventing the penetration of pansy epidermal cells by this pathogen. Even at $4 \mathrm{~h} \mathrm{PI}$, slender penetration hyphae had emerged from germ tube tips and grown into and completely through some papillae (Fig. 2A through E). As a penetration hypha grew through a papilla, its tip became coated with a thin layer of electron-dense material (Fig. $2 \mathrm{C}$ through $\mathrm{E}$ ). This layer ruptured as the tip of the penetrating hypha emerged from a papilla and expanded to form a swollen, globose, terminal infection vesicle (Fig. 3A and B). However, remains of the electron-dense layer persisted at the point of continuity between a penetration hypha and its infection vesicle (Fig. 3A and B).

As an infection vesicle formed, a septum developed in the proximal end of the penetration hypha. This septum (Fig. 3C) possessed a central pore with which Woronin bodies were associated.

Although a few infection vesicles were observed in 4-h-PI samples, they were much more common in 6-h-PI samples. Each vesicle was surrounded by a thin layer of host cytoplasm (Fig. 3A and B) which sometimes also included the host cell nucleus. This layer of cytoplasm separated the vesicle from the host cell central vacuole into which it protruded. Judging from the appearance of host cell organelles (Fig. 3B), it appeared that the host cells were alive at the time of infection vesicle formation.

Infection vesicles of $T$. basicola were indeterminate in growth. At $6 \mathrm{~h} \mathrm{PI}$, infection hyphae were observed emerging from infection vesicles (Fig. 3D). By the time these hyphae formed, evidence of necrosis was apparent in invaded cells. In such cells the host cell membrane typically was separated from the inner surface of the host cell wall, and the tonoplast of the vacuole had broken down, allowing host organelles to enter vacuolar space (Fig. 3D and E). In some cases, the nucleus of the necrotic host cell partially surrounded an infection vesicle and its hypha (Fig. 3E).

By 8 h PI, some infection hyphae had contacted and penetrated cortical cells in spite of papilla formation by these cells (Fig. 4A and B). Hyphae observed in cortical cells were 
branched and extremely constricted at their septa. These constrictions gave each hypha a distinctly beaded or lanceshaped appearance (Fig. 4C). Hyphae grew up and down the root and also penetrated further into the root. By $24 \mathrm{~h}$ PI, necrotic cortical cells were colonized extensively by intracellular hyphae of $T$. basicola (Fig. 4D). No evidence of intercellular hyphal growth was observed.
As noted above, the sequence of events that occurred in the infection of washed roots was slightly different than described above for roots grown on filter paper. We rarely observed evidence of cytoplasm and nuclei in epidermal cells of washed roots. When penetrated by $T$. basicola hyphae, epidermal cells did not form papillae (Fig. 4E and F). The hyphae of T. basicola that penetrated epidermal cells of washed roots (Fig. 4E and F) had a greater dia-

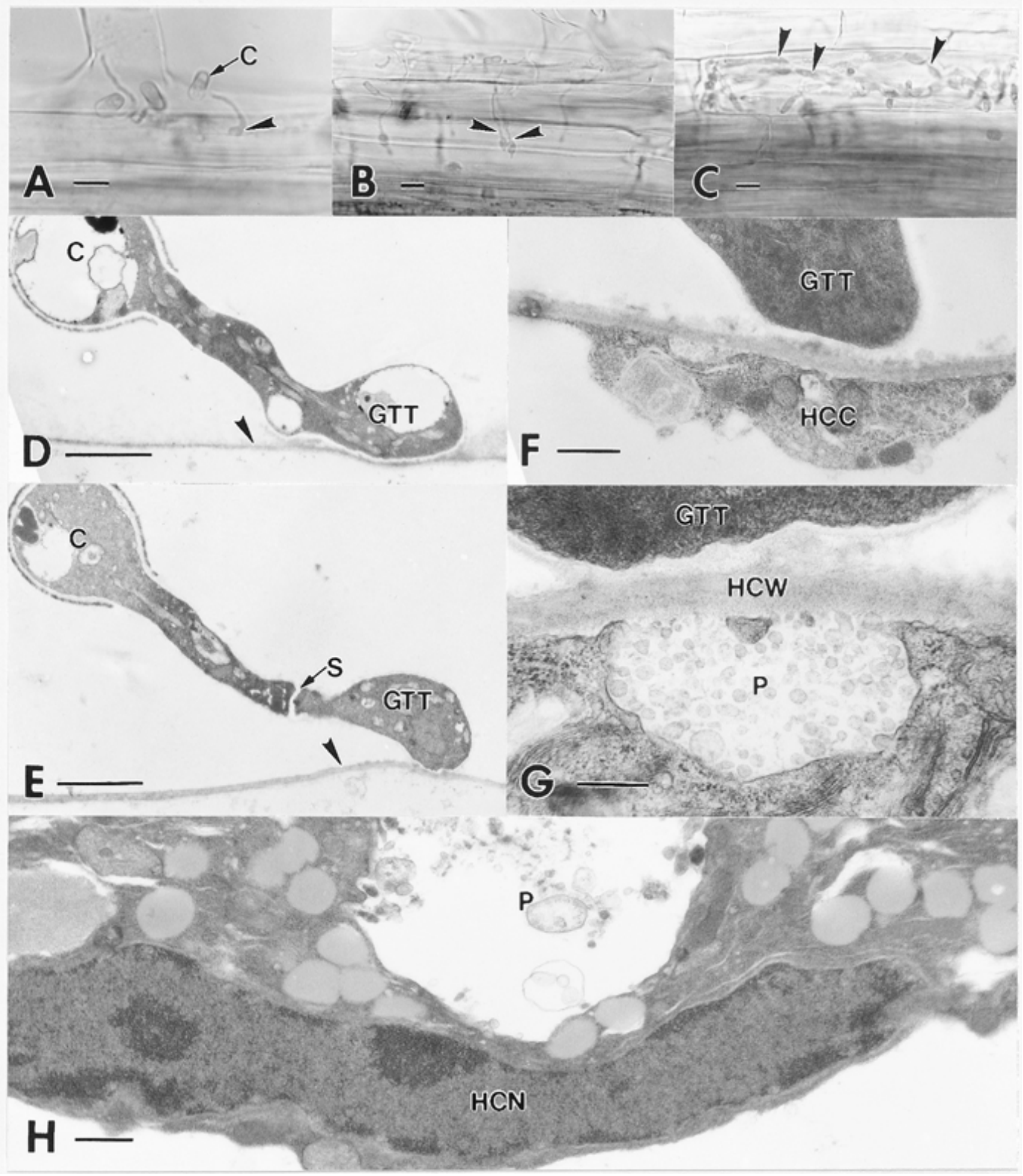

Fig. 1. Interactions of Thielaviopsis basicola with pansy roots as seen in light micrographs of flat embedded roots (A through C) and transmission electron micrographs (D through H) of thin sections. A, A swollen germ tube tip (arrowhead) in contact with a root at 3 h postinoculation. The parent conidium is visible at C. Bar $=10 \mu \mathrm{m}$. B, Infection structures (arrowheads) in epidermal cells at $8 \mathrm{~h}$ postinoculation. Bar $=15 \mu \mathrm{m}$. C, Hyphae (arrowheads) in a cortical cell at $24 \mathrm{~h}$ postinoculation. Bar $=10 \mu \mathrm{m}$. D, and E, Swollen germ tube tips (GTT) in contact with roots at $3 \mathrm{~h}$ postinoculation. Cross sections of parent conidia are shown at C. A septum (S) is visible in the germ tube shown in E. Bars $=2.0 \mu \mathrm{m}$. F, Aggregated host cell cytoplasm (HCC) near a germ tube tip (GTT) at $3 \mathrm{~h}$ postinoculation. Bar $=0.5 \mu \mathrm{m}$. G, Developing papilla $(\mathrm{P})$ near a germ tube tip $(\mathrm{GTT})$ at $3 \mathrm{~h}$ postinoculation. The host cell wall is visible at $\mathrm{HCW}$. Bar $=0.3 \mu \mathrm{m}$. $\mathbf{H}$, Host cell nucleus $(\mathrm{HCN})$ near a large papilla $(\mathrm{P}) . \mathrm{Bar}=0.5 \mu \mathrm{m}$. 
meter than the slender penetration hyphae described above. Once inside epidermal cells, these hyphae grew toward the root cortex. When contacted by these hyphae, cortical cells responded by forming papillae (Fig. 4F). However, papilla formation was not successful in preventing cortical cell invasion. The subsequent events involving the formation of a penetration hypha, infection vesicle, and infection hypha in a cortical cell of a washed root were identical to those observed in epidermal cells of roots produced on filter paper.

\section{DISCUSSION}

As noted in tobacco by Hood and Shew (7) and in various other types of plants by other researchers $(3,11,13)$, root hairs have been identified as primary penetration sites for $T$. basicola. However, this pathogen also has been reported to enter host roots through non-root hair epidermal cells $(9,15)$ as well as through wounds $(1,21,24)$. While we did not observe root hair penetration in pansy roots, the overall sequence of events we observed in other

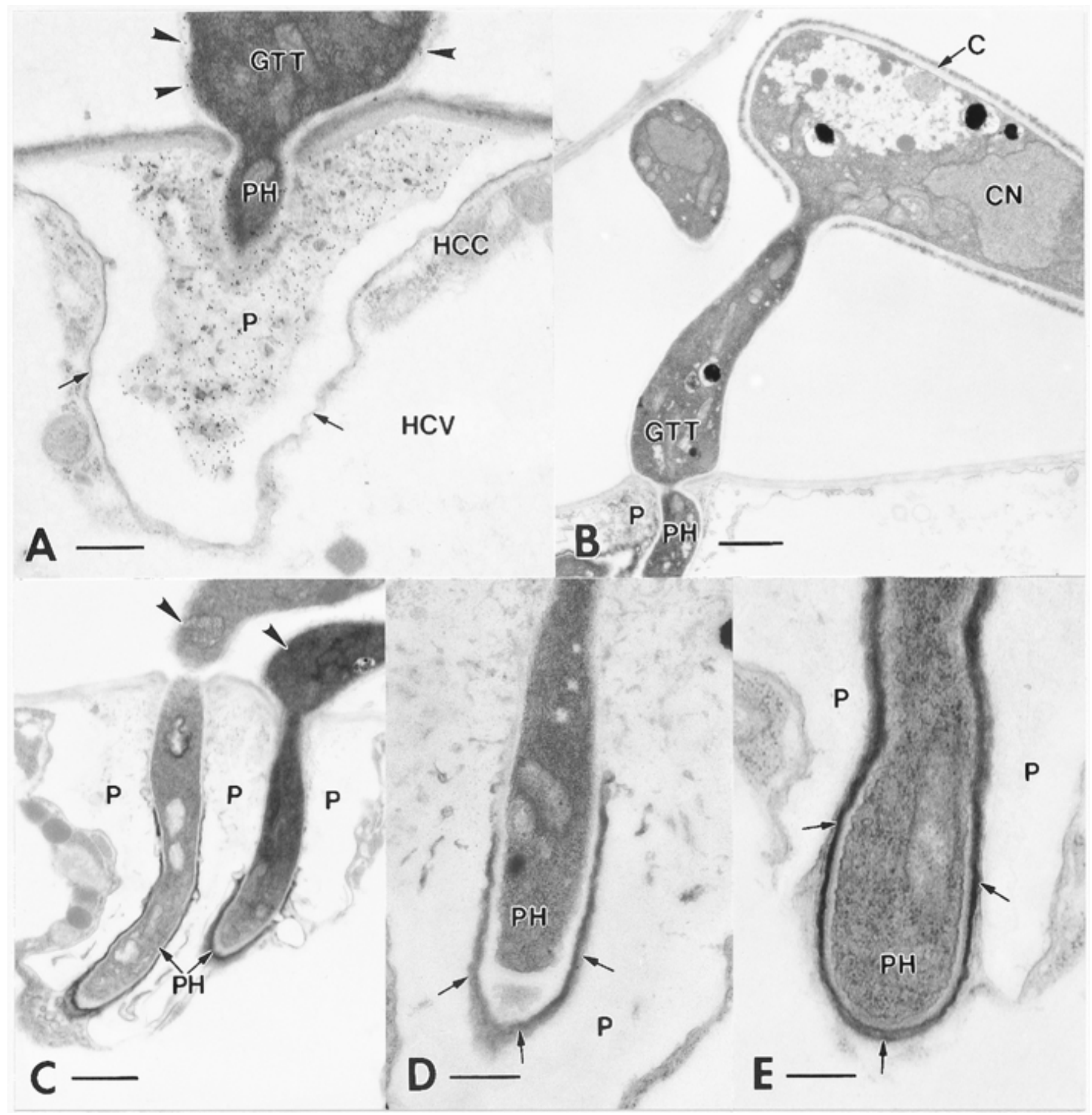

Fig. 2. Transmission electron micrographs of the penetration of pansy root epidermal cells by Thielaviopsis basicola. A, A well-developed papilla (P) at $4 \mathrm{~h}$ postinoculation formed in response to a germ tube tip (GTT) and penetration hypha (PH). Gold labeling of the central papilla core for callose is evident. Some labeling of (1-3)- $\beta$-glucans in the fungus wall also is apparent (arrowheads). The invaginated host cell plasma membrane (arrows) separates the electron transparent papilla margin from the host cell cytoplasm $(\mathrm{HCC})$ and vacuole $(\mathrm{HCV})$. Bar $=0.5 \mu \mathrm{m}$. B, A germinated conidium $(\mathrm{C})$ at $4 \mathrm{~h}$ postinoculation with a swollen germ tube tip (GTT) and a penetration hypha $(\mathrm{PH})$. The conidium nucleus $(\mathrm{CN})$ and a papilla $(\mathrm{P})$ are visible. Bar $=1.0 \mu \mathrm{m}$. $\mathbf{C}$, Two penetration hyphae $(\mathrm{PH})$ arising from two germ tube tips (arrowheads) that developed very close to one another. A large common papilla $(\mathrm{P})$ surrounds the penetration hyphae. Bar $=1.0 \mu \mathrm{m}$. D, Tip of a penetration hypha $(\mathrm{PH})$ at $4 \mathrm{~h}$ postinoculation in a papilla $(\mathrm{P})$. Its tip is ensheathed by a thin layer of electron-dense material (arrows). Bar $=0.5 \mu \mathrm{m}$. E, Tip of penetration hypha $(\mathrm{PH})$ exiting the surrounding papilla $(\mathrm{P})$ at $4 \mathrm{~h}$ postinoculation. The hypha is coated by a thin layer of electron dense material (arrows). $\mathrm{Bar}=0.3 \mu \mathrm{m}$. 
epidermal cells was very similar to that described for tobacco root hairs by Hood and Shew (8). Below, we compare our major observations to those of both Hood and Shew (8) and other researchers $(3,15,20,29)$ who have studied the infection of roots by $T$. basicola.

As we also observed for pansy roots, Hood and Shew (8) reported that many germ tubes of $T$. basicola continued to elongate after making contact with root surfaces. They used the term "inductive contact" to describe the production of slightly swollen germ tube and hyphal tips that subsequently gave rise to slender penetration hyphae that entered host cells. Whether or not these tips should be considered as appressoria is unclear. Hood and Shew (8) suggested that use of this term should be deferred until the function of adhesion could be confirmed for these structures.

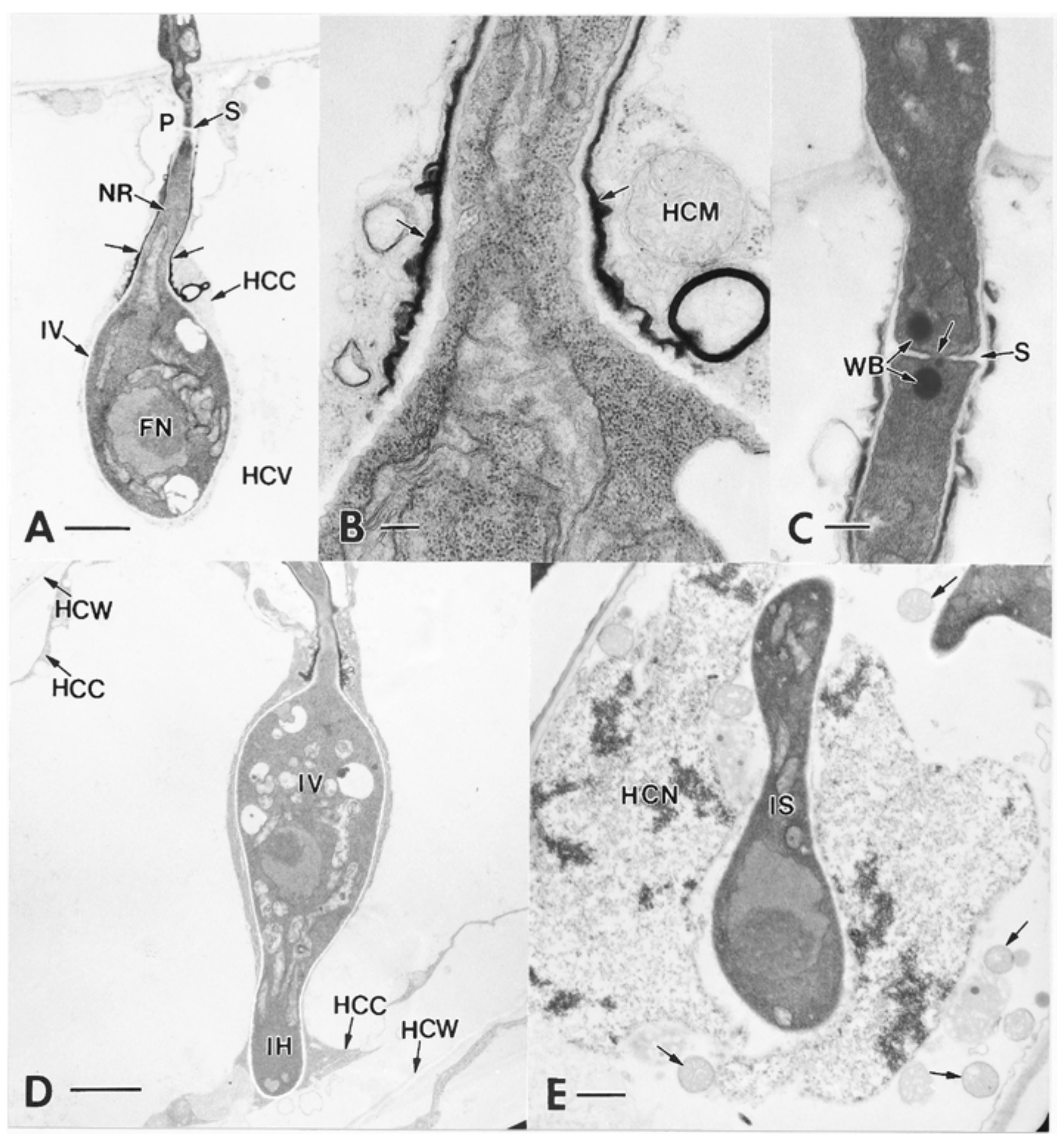

Fig. 3. Transmission electron micrographs of Thielaviopsis basicola in pansy root epidermal cells. A, A mature infection structure at $6 \mathrm{~h}$ postinoculation. Visible are the neck region (NR) coated with electron-dense material (arrows) and the infection vesicle (IV) with its nucleus (FN). A septum is visible at S. Visible in the host cell are a papilla $(\mathrm{P})$ and a thin layer of cytoplasm $(\mathrm{HCC})$ that separates the infection structure from the vacuole $(\mathrm{HCV})$. Bar $=1.5 \mu \mathrm{m}$. B, High magnification view of the electron-dense material (arrows) from A, An intact mitochondrion (HCM) is visible in the host cell cytoplasm. Bar $=0.1 \mu \mathrm{m}$. $\mathbf{C}$, A septum (S) in the neck region of an infection structure. The septal pore (arrow) and Woronin bodies (WB) are visible. Bar $=0.25 \mu \mathrm{m}$. D, An infection hypha (IH) emerging from an infection vesicle (IV) at $8 \mathrm{~h}$ postinoculation. The host cell cytoplasm (HCC) has pulled away from the host cell wall (HCW). $\mathrm{Bar}=2.5 \mu \mathrm{m}$. E, A necrotic nucleus (HCN) partially surrounding an infection structure (IS) at $8 \mathrm{~h}$ postinoculation. Host cell mitochondria (arrows) are evident in the vacuolar space. $\mathrm{Bar}=1.0 \mu \mathrm{m}$. 
In our opinion, however, the fact that the germ tube tips of $T$. basicola remained in contact with pansy epidermal cells throughout the physical and chemical rigors of sample preparation for TEM provides strong evidence for their adhesive nature. On the other hand, it is clear that these structures are not as morphologically complex as the appressoria of some plant-pathogenic fungi. Even the process of septum formation near a germ tube tip of $T$. basicola was an inconsistent event.

The initial response of a pansy root epidermal cell to a swollen germ tube tip of $T$. basicola was very similar to that described in tobacco root hairs by Hood and Shew (8). In both cases, host cell cytoplasm became aggregated near germ tube tips. In tobacco root hairs, Hood and Shew (8) were able to observe cytoplasmic streaming in living cells and reported that cytoplasmic aggregation occurred 5 to $10 \mathrm{~min}$ after contact with the germ tube or hyphal tips. They also reported that the host cell nucleus sometimes migrated to a penetration site. Penetration of root hairs occurred 15 to 20 min after contact. As in pansy roots, penetration hyphae were slender and threadlike. Vesicle formation in tobacco root hairs occurred 65 to $70 \mathrm{~min}$ after initial contact. Although Hood and Shew (8) did not report the development of papillae in response to germ tube tips, they did demonstrate a distinct callose

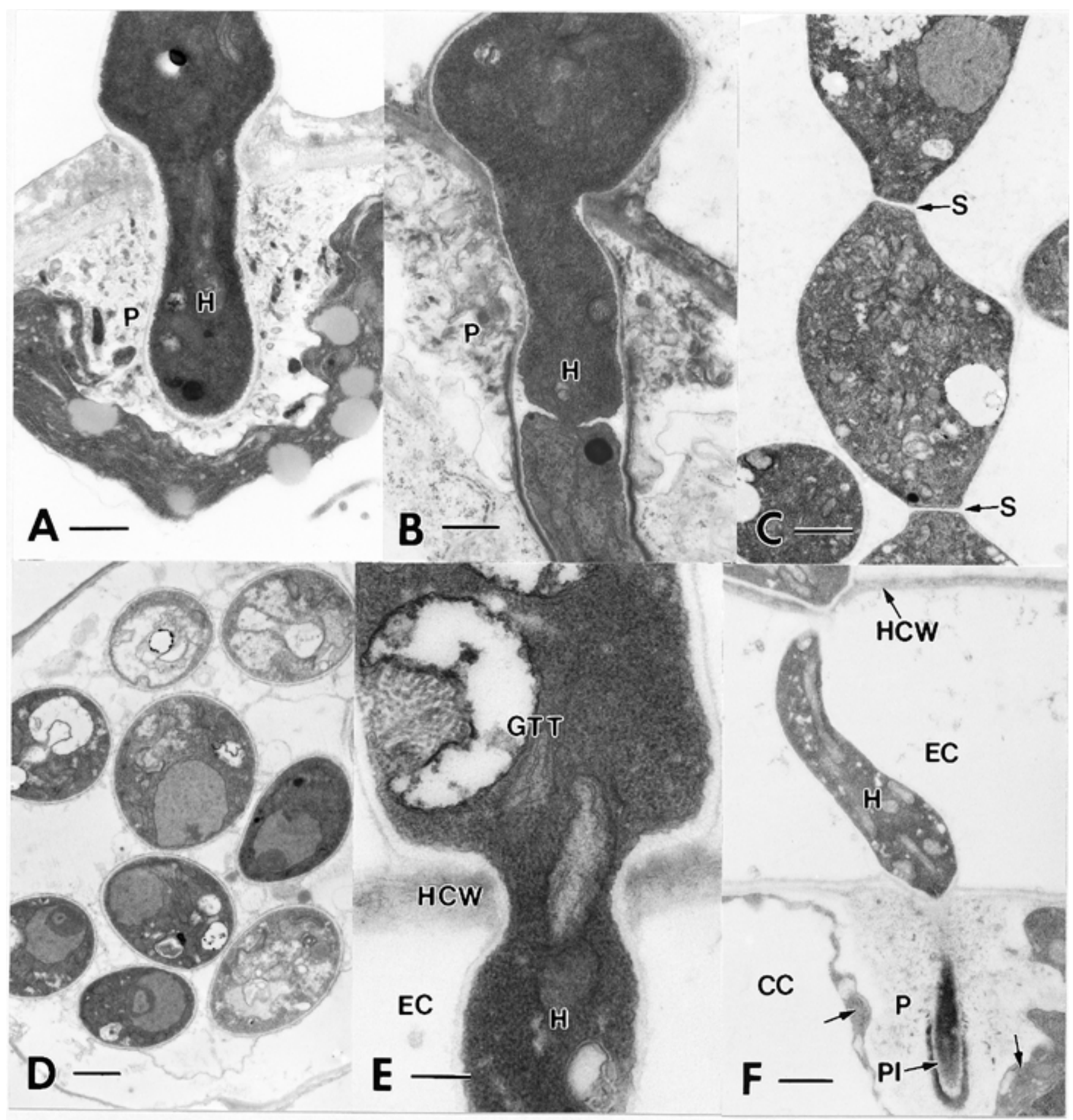

Fig. 4. Transmission electron micrographs of Thielaviopsis basicola in pansy roots . A, and B, Penetration of cortical cells at $8 \mathrm{~h}$ postinoculation. A papilla (P) surrounds each hypha $(\mathrm{H})$. Bars $=0.5 \mu \mathrm{m}$. C, Characteristic beaded appearance of a hypha in a cortical cell at $24 \mathrm{~h}$ postinoculation. Septa are visible at $\mathrm{S}$. Bar $=$ $1.0 \mu \mathrm{m}$. D, Cross section of a necrotic cortical cell containing numerous hyphae at $24 \mathrm{~h}$ postinoculation. Bar $=1.0 \mu \mathrm{m}$. E, Hypha $(\mathrm{H})$ from a swollen germ tube tip (GTT) extending onto an epidermal cell (EC) of a washed root at $3 \mathrm{~h}$ postinoculation. The host cell wall is shown at HCW. Bar $=0.15 \mu \mathrm{m}$. F, Hypha (H) that had grown through an epidermal (EC) cell of a washed root and into a cortical cell (CC) at $4 \mathrm{~h}$ postinoculation. The cell wall of the epidermal cell is visible at HCW. The slender penetration hypha (PI) is surrounded by a papilla (P). Host cell cytoplasm is visible at the arrows. Bar $=1.0 \mu \mathrm{m}$. 
collar around a penetration hypha and a portion of its infection vesicle at 75 to $80 \mathrm{~min}$ after contact. However, we believe that papilla formation actually occurred very early in infected tobacco root hairs. It appears that papillae are visible in association with the penetration hyphae shown in Figure 3D and E of Hood and Shew's paper. The outlines of the transparent areas visible around the tips of these hyphae correspond very closely to the outline of the papilla shown in our Figure $2 \mathrm{~A}$.

Additional indirect evidence that papilla formation occurred very early in the penetration of tobacco root hairs can be found in the transmission electron micrograph included as Figure 5A by Hood and Shew (8). In this micrograph, a thin layer of electrondense material is visible on the surface of the penetration hypha as well as on a portion of the infection vesicle. This layer appears to be identical to the electron-dense layer visible in our Figure 3B. In pansy cells this layer of material appeared to be derived from the layer of electron-dense material that formed around the tip of an infection hypha as it grew through a papilla. The exact nature of this material is unknown. However, the material is reminiscent of electron-dense material observed in various plants infected with either smut fungi (2) or certain oomycetes $(4,5,6,28)$. Such material has been referred to as either extrahaustorial matrix material or penetration matrix material. To date, neither the origin nor the chemical composition of this type of material is known.

The observations of Hood and Shew $(7,8)$ and others $(3,13,26)$ support our belief that pansy root epidermal cells were alive at least until the onset of the development of an infection hypha from an infection vesicle. We agree with Hood and Shew's (8) suggestion that $T$. basicola is a hemibiotroph. More specifically, however, we believe that $T$. basicola qualifies as a necrotrophic hemibiotroph. Our observations suggest that host cell necrosis began in invaded pansy root epidermal cells as early as $8 \mathrm{~h}$ PI and that by $24 \mathrm{~h}$ PI extensive death of cortical cells also had occurred. In the case of tobacco roots attacked by $T$. basicola, Hood and Shew (8) expressed the opinion that the duration of the biotrophic phase was on the order of days rather than a few hours.

Our observations of washed pansy roots suggest that the epidermal cells of these roots either were killed during the washing process or, at least, damaged to the point that they were unable to respond to germ tubes and penetration hyphae of T. basicola. Only very rarely did we observe any evidence of cytoplasmic aggregation and papilla formation in any of these cells. However, inclusion of washed roots in this study still yielded valuable information. By examining the interaction of T. basicola with washed roots, it became apparent that this pathogen formed its distinctive infection structures only in healthy, living cells. In the case of washed roots, infection structures did not develop until the pathogen had grown through a nonresponsive epidermal cell and into an underlying cortical cell. Interestingly, Hood and Shew (8) also reported that the penetration of dead tobacco root hair cells by $T$. basicola was common and that infection structures did not develop in dead cells. This type of behavior suggests a more complex host-pathogen relationship than would be expected in a necrotrophic pathogen.

Our observations regarding the location of callose in pansy root cell papillae agree with those of Enkerli et al. (5) for soybean root cell papillae formed in response to the oomycete stem and root rot pathogen Phytophthora sojae. Using the same antibody against (13 )- $\beta$-glucans that we employed in this study, they (5) also reported that labeling was confined to dark, irregular inclusions within the central core of a soybean papilla and absent from the electrontransparent papilla margin. As noted by Enkerli et al. (5), the pattern of callose labeling in papillae seems to vary from one plant species to the next, suggesting possible differences between such deposits.

The overall morphology of a T. basicola infection structure is quite similar to that of a haustorium of the hemibiotrophic leaf pathogen Entomosporium mespili (14). Each of these structures possesses a slender neck region with a single septum and an enlarged distal end that contains a single nucleus. However, the distal end or haustorial body of E. mespili is slightly more elongated than the globose infection vesicle of $T$. basicola. In addition, haustoria of $E$. mespili are determinate in growth and do not give rise to hyphae that exit infected cells, as is the case for the infection structures of $T$. basicola. Each haustorium of $E$. mespili retains its distinctive morphology even after its host cell has undergone necrosis (14). Host cell necrosis in leaves infected by $E$. mespili does not appear to take place until sporulation begins. This suggests that E. mespili should be considered a biotrophic hemibiotroph.

The beaded or lance-shaped morphology of the mature intracellular hyphae of $T$. basicola noted in this study has been reported by numerous other researchers $(10,13,25)$. This distinctive hyphal morphology appears to be characteristic of this species.

\section{LITERATURE CITED}

1. Baard, S. W., and Laubsher, C. 1985. Histopathology of blackhull incited by Thielaviopsis basicola in groundnuts. Phytophylactica 17:85-88.

2. Bauer, R., Mendgen, K., and Oberwinkler, F. 1994. Cellular interaction of the smut fungus Ustacystis waldsteiniae. Can. J. Bot. 73:867-883.

3. Christou, T. 1962. Penetration and host-parasite relationships of Thielaviopsis basicola in the bean plant. Phytopathology 52:194-198.

4. Coffey, M. D., and Wilson, U. E. 1983. An ultrastructural study of the late-blight fungus Phytophthora infestans and its interaction with the foliage of two potato cultivars possessing different levels of general (field) resistance. Can. J. Bot. 61:2669-2685.

5. Enkerli, K., Hahn, M. G., and Mims, C. W. 1997. Immunogold localization of callose and other plant cell wall components in soybean roots infected with the oomycete Phytophthora sojae. Can. J. Bot. 75:1509-1517.

6. Hickey, E. L., and Coffey, M. D. 1977. A fine-structural study of the pea downy mildew fungus Peronospora pisi in its host Pisum sativum. Can. J. Bot. 55:2845-2858.

7. Hood, M. E., and Shew, H. D. 1996. Pathogenesis of Thielaviopsis basicola on a susceptible and resistant cultivar of burley tobacco. Phytopathology 86:38-44.

8. Hood, M. E., and Shew, H. D. 1997. Initial cellular interactions between Thielaviopsis basicola and tobacco root hairs. Phytopathology 87:228235.

9. Jones, B. L. 1991. Penetration and development of Chalara elegans in peanut (Arachis hypogaea). Phytophylactica 23:81-84.

10. Latunde-Duda, A. D., O’Connell, R. J., Nash, C., Pring, R. J., Lucas, J. A., and Bailey, J. A. 1996. Infection process and identity of the hemibiotrophic anthracnose fungus (Colletotrichum destructivum) from cowpea (Vigna unguiculata) Mycol. Res. 100:1133-1141.

11. Linderman, R. G., and Toussoun, T. A. 1968. Pathogenesis of Thielaviopsis basicola in nonsterile soil. Phytopathology 58:1578-1583.

12. Luttrell, E. S. 1994. Parasitism of fungi on vascular plants. Mycologia 66:1-15.

13. Mathre, D. E., Ravenscroft, A. V., and Garber, R. H. 1966. The role of Thielaviopsis basicola as a primary cause of yield reduction in cotton in California. Phytopathology 56:1213-1216.

14. Mims, C. W., Sewall, T. C., and Richardson, E. A. 2000. Ultrastructure of the host-pathogen relationship in Entomosporium leaf spot disease of Photinia. Int. J. Pl. Sci.161:291-295.

15. Nan, Z. B., Long, P. G., Skipp, R. A., and Hopcroft D. H. 1992. Microscopy of invasion of red clover roots by Trichocladium basicola, and effects of benomyl and procloraz. Plant Pathol. 41:449-461.

16. O'Connell, R. J., and Bailey, J. A. 1991. Hemibiotrophy in Colletotrichum lindemuthianum. Pages 211-222 in: Electron Microscopy of Plant Pathogens. K. Mendgen and D. E. Leseman, eds. SpringerVerlag, New York.

17. O'Connell, R. J., Uronu, A. B., Waksman, G., Nash, C., Keon, J. P. R., and Bailey, J. A. 1993. Hemibiotrophic infection of Pisum sativum by Colletotrichum truncatum. Plant Pathol. 42:774-783.

18. Otani, Y. 1962. Studies on the black root rot disease caused by Thielaviopsis basicola (Berk. \& Br.) Ferraris. Bull. Okayama Tob. Exp. Stn. 23:1-118.

19. Parbery, D. G. 1996. Trophism and the ecology of fungi associated with plants. Biol. Rev. 71:473-527.

20. Prinsloo, G. C., Baard, S. W. and Ferreira, J. F. 1992. A scanning electron microscope study of the infection and colonization of chicory roots by Thielaviopsis basicola. Phytophylactica 24:293-296. 
21. Punja, Z. K., Chittaranjan, S., and Gaye, M. M. 1992. Development of black root rot caused by Chalara elegans on fresh market carrots. Can. J. Plant Pathol. 14:299-309.

22. Roberts, D. R., Mims, C. W., and Fuller, M. S. 1996. Ultrastructure of the ungerminated conidium of Blumeria graminis f. sp. hordei. Can. J. Bot. 74:231-237.

23. Rowley, C. R., and Moran, D. T. 1975. A simple procedure for mounting wrinkle-free sections on formvar-coated slot grids. Ultramicrotomy 1:151-155.

24. Stover, R. H. 1950. The black root rot disease of tobacco. I. Studies on the causal organism Thielaviopsis basicola. Can. J. Res. Sect. C. Bot. Sci. 28:445-470.

25. Taylor, J., and Mims, C. W. 1991. Fungal development and host cell responses to the rust fungus Puccinia substriata var. indica in seedlings and mature leaves of susceptible and resistant pearl millet. Can. J. Bot. 69:1207-1219.

26. Tsao, P. H., and van Gundy, S. D. 1962. Thielaviopsis basicola as a citrus root pathogen. Phytopathology 52:781-786.

27. Wei, Y. D., Byer, K. N., and Goodin, P. H. 1997. Hemibiotrophic infection of round-leaved mallow by Colletotrichum gloesporioides $\mathrm{f}$. sp. malvae in relation to leaf senescence and reducing agents. Mycol. Res. 101:357-364.

28. Wetherbee, R., Hinch, J. M., and Clark, A. E. 1985. Response of Zea mays roots to infection with Phytophthora cinnamomi. II. The cortex and stele. Protoplasma 126:188-197.

29. Wick, R. L., and Moore, L. D. 1983. Histopathology of root disease incited by Thielaviopsis basicola in Ilex crenata. Phytopathology 73:561-564. 